\title{
ANALISIS PENGARUH STRUKTUR KEPEMILIKAN DAN PERTUMBUHAN PERUSAHAAN TERHADAP KETERLAMBATAN AUDIT
}

\author{
Raja Andiani Sebriwahyuni* dan Bagas Kurniawan* \\ *Program Studi Akuntansi, Fakultas Ekonomi \\ Universitas Internasional Batam \\ Email:ade@uib.ac.id; bagaskurniawan1642031@gmail.com
}

\begin{abstract}
This main focus of this study is to analysis the effect of the company ownership and company growth on audit report lag. The target sample of this study consists of companies listed in Indonesian Stock Exchange (IDX) during 2014-2018. This study using purposive sampling method to collected data. There are 428 companies that required and proceed with panel regression to analyze the effect of independent variable on dependent variable. The result however show that only foreign ownership has significant impact on audit report lag, but managerial ownership, institutional ownership, company growth, and ownership concentration has insignificant impact on audit report lag.
\end{abstract}

Keywords: audit report lag, company ownership, company growth

\section{PENDAHULUAN}

Keterlambatan audit adalah perbedaan jarak waktu antara tanggal tutup buku laporan keuangan dan laporan auditor disajikan kepada khalayak umum (Hashim, 2017). Keterlambatan audit terjadi karena laporan tahunan yang dipublikasikan harus diaudit oleh akuntan publik yang telah tercatat di Bursa Efek Indonesia (BEI). Sesuai dengan aturan Otoritas Jasa Keuangan (OJK) No.29/Pojk.04/2016 yaitu bagi perusahaan yang terdaftar di BEI wajib melaporkan laporan keuangan tahunan yang telah dilakukan audit maksimal 4 bulan setelah tahun buku berakhir kepada OJK (OJK, 2016). Salah satu factor yang dipengaruhi keterlambatan audit adalah ketepatan waktu penyajian laporan keuangan.

Kontribusi yang diberi berupa informasi yang akurat yang dibutuhkan oleh pemegang kepentingan perusahaan dan pengguna lainnya untuk memberikan suatu keputusan (Mazkiyani \& Handoyo, 2017). Sesuai dengan pernyataan Ohaka dan Akani (2017), ketepatan waktu dalam penyajian laporan keuangan juga dianggap vital bagi investor, karena relevansi informasi yang disajikan laporan keuangan tahunan menurun seiring dengan meningkatnya waktu atas lamanya laporan tahunan diberikan kepada publik. Keterlambatan audit merupakan salah satu faktor krusial dalam keakuratan informasi yang ada didalam laporan tahunan, maka penting untuk menemukan faktor faktor apa saja yang menjadi peneyebab keterlambatan audit dan memaksimalkan dalam penggunaan informasi untuk penyusunan jadwal audit. Beberapa faktor faktor yang mempengaruhi keterlambatan audit adalah company size, ownership concerntration, managerial ownership, foreign ownership, institutional ownership dan auditor reputation. Company size dan kepemilikan berpengaruh besar terhadap keterlambatan audit karena kegiatan yang kompleks, beraneka ragam, dan transaksi yang harus diperiksa dengan sungguh sungguh dapat menambah keterlambatan penyampaian laporan tahunan ke publik (Hashim, 2017).

Oleh karena, keterlambatan audit merupakan suatu objek yang merarik untuk diteliti lebih lanjut. penulis merumuskan penelitian dengan judul: "analisis pengaruh struktur kepemilikan dan pertumbuhan 


\section{perusahaan terhadap keterlambatan audit".}

\section{KAJIAN LITERATUR PENGEMBANGAN HIPOTESIS}

Dyer dan McHugh mengkelompokkan keterlambatan audit menjadi 3 jenis, yaitu:

a. Keterlambatan atas ketersediaan, yaitu jarak waktu antara tutup buku laporan tahunan dengan tersedianya laporan keuangan di pasar modal Australia.

b. Keterlambatan atas penandatanganan auditor, yaitu jarak waktu antara tutup buku laporan tahunan dengan adanya opini auditor pada laporan audit.

c. Seluruh keterlambatan, yaitu jarak waktu antara tutup buku laporan tahunan dengan terpublikasinya laporan keuangan tahunan oleh pasar modal di Australia.

\section{Pengaruh Konsentrasi Kepemilikan terhadap Keterlambatan Audit}

Saham yang termasuk konsentrasi kepemilikan ialah saham yang sebagian besar dipegang segelintir individu ataupun grup, dimana kuasa yang dimiliki selaras dengan kepemilikan yang dimiliki sehingga memicu lambatnya penerbitan laporan tahunan dibandingkan dengan kepemilikan yang terdispersi karena informasi pasti telah didapat terlebih dahulu sebelum di terbitkannya laporan tahunan (Mouna \& Anis, 2013b). Penelitian terdahulu tentang konsentrasi kepemilikan positif terhadap keterlambatan audit yaitu oleh Mouna dan Anis (2013a, 2013b), lalu ada yang menyatakan tidak menemukan pengaruh signifikan yaitu oleh Afify (2009), Alsmady (2018), Lee dan Jahng (2008), Setiawan dan Nahumury (2014).

$H_{1}$ : Konsentrasi kepemilikan mempunyai pengaruh positif terhadap keterlambatan audit

\section{Pengaruh Kepemilikan Manajerial terhadap Keterlambatan Audit \\ Kepemilikan managerial adalah} kepemilikan atas saham yang diberikan kepada para direksi dengan harapan memotivasi mereka untuk meningkatkan kinerja perusahaan. Puasa dan Ahmad (2014) beranggapan bahwa pemegang saham dan direksi akan sejalan saat direksi memiliki kepemilikan di perusahaan. Oleh karena itu, pasti meningkatkan kehati hatian mereka dalam pengambilan keputusan dan pasti mereka akan berusaha semaksimal mungkin dalam ketepatan penyajian laporan keungan untuk para pemangku kepentingan (Hashim, 2017). Penelitian terdahulu tentang kepemilikan manajerial berpengaruh negatif terhadap keterlambatan audit yaitu oleh Hashim (2017), Puasa dan Ahmad (2014). Namun, terdapat penelitian yang mendeapati kepemilikan manajerial tidak berpengaruh signifikan yaitu penelitian oleh Alsmady (2018), Fujianti (2016), Puspitaningrum dan Atmini (2012).

$\mathrm{H}_{2}$ : Kepemilikan manajerial mempunyai pengaruh negatif terhadap keterlambatan audit

\section{Pengaruh Kepemilikan Asing terhadap Keterlambatan Audit}

Kepemilikan asing adalah kepemilikan atas saham yang dimiliki oleh orang luar negeri sebagai salah satu cara agar bisa memantau manajemen karena sifatnya mirip dengan kepemilikan institutional dan menjadi salah satu mekanisme efektif yang dapat melengkapi struktur tata kelola perusahaan (Togasima \& Christiawan, 2012). Ketatnya pengawasan oleh pemilik asing membuat kinerja perusahaan lebih baik dan jika kepemilikannya besar maka mereka pasti akan menggunakan standar internasional dan diaudit oleh perusahaan audit terkemuka (Huafang \& Jianguo, 2007). Penelitian terdahulu tentang kepemilikan asing berpengaruh negatif terhadap keterlambatan audit yaitu oleh Hashim (2017), Huafang dan Jianguo (2007), Puasa dan Ahmad (2014). Sedangkan terdapat penelitian berpengaruh positif yaitu penelitian yang dilakukan oleh 
Lee, Rhee, dan Yoon (2018); Tazik dan Mohamed (2014).

$H_{3}$ : Kepemilikan asing mempunyai pengaruh negatif terhadap keterlambatan audit

\section{Pengaruh Kepemilikan institutional terhadap Keterlambatan Audit}

Kepemilikan institutional adalah penanaman modal yang berasal dari sebuah grup investasi atau dari institusi keuangan. Kehadiran institusi keuangan atau grup investasi dalam struktur kepemilikan dipandang sebagai elemen penting dari tata kelola perusahaan. Karena pengalaman mereka dan pengetahuan lembaga memberikan pengawasan dan pemantauan atas eksekutif dan disiplin pemilik dominan (Mouna \& Anis, 2013b). Ketika kepemilikan dari institusi ini tergolong besar maka akan meningkatkan kinerja perusahaan dan juga mengurangi jangka waktu keterlambatan audit, karena mereka hanya percaya atau tertarik dengan orientasi jangka pendek dimana itu dapat berubah ubah seiring berjalannya waktu (Hashim, 2017). Penelitian terdahulu tentang kepemilikan institusional berpengaruh negatif terhadap keterlambatan audit yaitu oleh Puasa dan Ahmad (2014). Sedangkan penelitian lain yang berpendapat bahwa kepemilikan institusional tidak memiliki pengaruh signifikan terhadap keterlambatan audit yaitu oleh Azhari dan Nuryatno (2019), Hashim (2017), Mohammed, Che-ahmad, dan Malek (2018), Mouna dan Anis (2013b).

$\mathrm{H}_{4}$ : Kepemilikan institusional mempunyai pengaruh negatif terhadap keterlambatan audit

\section{Pengaruh Pertumbuhan Perusahaan Terhadap Keterlambatan Audit}

Pertumbuhan perusahaan ialah salah satu faktor yang biasanya dapat mempengaruhi keterlambatan audit. Ismail dan Chandler (2004) menyatakan bahwa jika pertumbuhan perusahaan membaik maka dapat mempercepat suatu keterlambatan audit, namun jika pertumbuhan perusahaan menurun maka dapat memperlama keterlambatan audit. Penelitian terdahulu tentang pertumbuhan perusahaan berpengaruh negatif terhadap keterlambatan audit yaitu oleh Alsmady (2018); Chandler $\mathrm{Ku}$ Nor Izah $\mathrm{Ku}$ Ismail Roy (2004); Habib (2015). Berbeda dengan hasil penelitian (Durand, 2019), dimana penelitian itu meneumukan bahwa peertumbuhan perusahaan tidak berpengaruh signifikan.

$\mathrm{H}_{5}$ : Pertumbuhan perusahaan mempunyai pengaruh negatif terhadap keterlambatan audit

\section{METODE PENELITIAN}

Penelitian yang dilakukan bersifat kuantitatif, yaitu penelitian yang menguji suatu permasalahan atas suatu tren yang terjadi atau menguji hubungan antar variabel. Penelitian ini menganalisis tren, perbandingan, dan hubungan menggunakan uji satitistik. Sehingga hasilnya dapat menjelaskan pengaruh atau hubungan satu variabel terhadap variabel lainnya (Creswell, 2012). Objek penelitian ini menggunakan data sekunder. Kriteria sampel yang dipakai, yaitu entitas yang terdata di BEI dari tahun 2014 sampai dengan tahun 2018, terdapat kelengkapan data yang dibutuhkan selama periode penelitian seperti rangkuman saham dan total penjualan pada laporan tahunan, dan telah menyampaikan laporan tahunan yang sudah diaudit kepada BEI.

\section{Variable Dependen}

Keterlambatan audit dipilih sebagai variabel dependen. Pengukuran ini dihitung dengan dengan jarak waktu dari tutup buku tahunan sampai dengan terbitnya laporan tahunan yang sudah di audit (Ocak \& Özden, 2018).

\section{Variabel Independen}

Variabel independen pada penelitian ini adalah:

\section{Konsentrasi kepemilikan}

Konsentrasi kepemilikan dinilai dari proporsi persenan kepemilikan saham dominan (> 5\%) terhadap saham yang sudah diedarkan. 


\section{Kepemilikan Manajerial}

Kriteria kepemilikan manajerial ialah jika terdapat saham yang dipegang pihak eksekutif maupun direksi. Oleh karena itu toal ukur yang digunakan ialah persentase kepemilikan manajerial terhadap total saham yang sudah diedarkan (Fujianti, 2016).

\section{Kepemilikan Asing}

Kriteria kepemilikan asing ialah jika terdapat saham yang dipegang pihak asing atau pihak luar negeri. Oleh karena itu toal ukur yang digunakan ialah persentase kepemilikan asing terhadap keseluruhan saham yang sudah diedarkan (Alsmady, 2018).

\section{HASIL PENELITIAN \\ Statistik Deskriptif}

Tabel 1

Descriptive statistics result

Descriptive statistics result
\begin{tabular}{|l|c|r|r|r|r|}
\hline Variabel & N & Minimum & Maximum & Mean & Std. Deviation \\
\hline Audit delay & 2061 & 15 & 129 & 76,33 & 15,618 \\
\hline$\%$ owncon & 2061 & $5,50 \%$ & $99,99 \%$ & $71,5860 \%$ & $17,95675 \%$ \\
\hline$\%$ manow & 2061 & $0,00 \%$ & $87,33 \%$ & $2,4990 \%$ & $8,60877 \%$ \\
\hline$\%$ foriegnow & 2061 & $0,00 \%$ & $99,99 \%$ & $16,7582 \%$ & $25,14534 \%$ \\
\hline$\%$ instow & 2061 & $0,00 \%$ & $99,99 \%$ & $64,3722 \%$ & $24,62548 \%$ \\
\hline Growth & 2061 & $-1694,47 \%$ & $4161617 \%$ & $2090074 \%$ & $9169327 \%$ \\
\hline Ukuran perusahaan & 2061 & 22,376625 & 34,798751 & 28,693614 & 1,8064005 \\
\hline Valid N (listwise) & 2061 & & & & \\
\hline
\end{tabular}

Sumber : data sekunder yang diolah (2020).

Dari Tabel 1 menunjukkan bahwa keterlambatan audit terjadi di hari ke 15 hingga 129 hari setelah tutup buku dengan nilai rata rata keterlambatan audit selama 76,33 hari. Hal ini terjadi karena ada beberapa perusahaan yang di suspend atau sedang mengalami perubahan yang masif seperti PT. Modern Internasional ditahun 2017 telat 9 hari dikarenakan perubahan lini usaha, dimana awalnya berfokus pada SevenEleven sekarang berpindah ke lini usaha alat kesehatan.

Variabel kepemilikan terkonsentrasi memiliki nilai berkisar di antara 5,50\% sampai dengan 99,99\% menandakan ada beberpa perusahaan yang kepemilikan dimiliki oleh saham mayoritas hampir $100 \%$

\section{Kepemilikan institusional}

Kepemilikan institusional hanya dinilai berdasarkan saham yang dipegang oleh intitusi. Tolak ukur yang diguanakn ialah besarnya proporsi saham yang dipegang institusi terhadap total keseluruhan saham yang sudah diedarkan (Hashim, 2017).

\section{Pertumbuhan perusahaan}

Natural log of sales dipakai sebagai tolak ukur pertumbuhan perusahaan, Ismail, Mustapha, dan Ming (2012) menyatakan bahwa pengukuran pertumbuhan perusahaan paling tepat dengan menggunakan profitabilitas (total penjualan). 
dimiki oleh asing dan juga ada yang tidak dimiliki asing. Rentang nilai variabel kepemilikan institusional $0,00 \%$ hingga $99,99 \%$, hal ini disebabkan adanya perusahaan yang hampir dimiliki $100 \%$ oleh suatu intitusi seperti persuahaan BUMN yang saham mayoritasnya dimiliki oleh negara.

Variabel growth memiliki nilai antara $-1694,4700 \%$ hingga $41616169910 \%$ dengan nilai rata-rata senilai $91693271427 \%$ yang dimana selama 5 tahun terakhir terjadi pemberhentian sementara oleh BEI, penurunan keuntungan ataupun keuntungan yang terlalu tinggi, seperti kenaikan pendapatan PT Pan Brother Tbk sebesar $41616169910 \%$ ditahun 2018 akibat disuspensi tahun sebelumnya oleh BEI, dan PT Pool Advista Indonesia Tbk mengalami penurunan sebesar $-1694,4700 \%$ akibat kerugian ditahun 2016.

\section{Hasil Uji Outlier}

Penelitian ini melakukan uji outlier guna menghilangkan data ekstrem ataupun menyimpan dengan memakai program SPSS Versi 22, dengan kriteria nilai SDR diatas 1,96 hingga 1,96. Sehingga mendapati sekitar 79 sampel yang data terdeteksi outlier sehingga total sampel yang semula 2140 data berkurang menjadi 2061 data, dan selanjutnya dilakukan uji deksriptif.

\section{Uji Regresi panel}

Uji regresi panel dilakukan dengan menggunakan aplikasi E-views 10, E-views 10 bertujuan untuk memudahkan Uji chow serta uji Hausman dalam memilih permodelan yang tepat antara FEM dan REM. Hasil dari permodelan yang tepat akan membantu penelitian dalam melihat hasil uji t dan uji $\mathrm{f}$.

\section{Hasil Uji Chow}

Berikut Tabel 2 yang menjabarkan hasil uji chow yang akan menjadi acuan pertama dalam penentuan model yang tepat.
Tabel 2

Hasil Uji Chow
\begin{tabular}{|l|c|c|c|}
\hline Effects Test & Statistic & d.f. & Prob. \\
\hline $\begin{array}{l}\text { Cross-section } \\
\text { F }\end{array}$ & 8.206394 & $(425,1628)$ & 0.0000 \\
\hline $\begin{array}{l}\text { Cross-section } \\
\text { Chi-square }\end{array}$ & 2359.773598 & 425 & 0.0000 \\
\hline
\end{tabular}

Sumber: Data sekunder yang diolah (2020).

Tabel 2 memperlihatkan nilai probabitas pada hasil Cross-section Chisquare berada dinilai 0,000, dimana hasil tersebut menunjukkan bahwa permodelan terbaik adalah FEM karena memenuhi kriteria FEM yaitu nilai probabilitas <0,05. Namun, perlu pengujian Hausman guna menentukan model yang tepat.

\section{Hasil Uji Hausman}

Tabel 3

\section{Hasil Uji Hausman}

\begin{tabular}{|l|c|c|c|}
\hline $\begin{array}{l}\text { Test } \\
\text { Summary }\end{array}$ & Chi-Sq. Statistic & Chi-Sq. d.f. & Prob. \\
\hline $\begin{array}{l}\text { Cross- } \\
\text { section } \\
\text { random }\end{array}$ & 66.951633 & & \\
\hline
\end{tabular}

Sumber: Data sekunder yang diolah (2020).

Tabel 3 memperlihatkan nilai probabilitas pada Cross-section random berada dinilai 0,0000 . Hasil ini menambah bukti bahwa permodelan terbaik FEM karena 5emenuhi kriteria nilai probabilitas $<0,05$, sehingga model FEM akan digunakan dalam penelitian ini.

\section{Hasil Uji F}

Tabel 4

Hasil Uji F

\begin{tabular}{|c|c|c|c|}
\hline $\begin{array}{c}\text { Variabel } \\
\text { Dependen }\end{array}$ & F & Prob. & Kesimpulan \\
\hline Audit_delay & 9.34876 & 0.0000 & Signifikan \\
\hline
\end{tabular}

Sumber: Data sekunder yang diolah (2020).

Uji F digunakan untuk menguji layak tidaknya suatu model. Tabel 4 memberikan informasi bahwa nilai probabilitas berada dinilai 0,0000 ditambah dengan nilai $\mathrm{f}$ sebesar 9.34876 dan memenuhi kriteria nilai probabilitas < 0,05. Hasil ini menunjukkan model dapat digunakan dan menyatakan 
bahwa variabel independen berupa kepemilikan terkonsentrasi, kepemilikan manajerial, kepemilikan asing, kepemilikan institusional, dan pertumbuhan perusahaan secara simultan berpengaruh terhadap variabel dependen keterlambatan audit.

\section{Hasil Uji t}

Tabel 5

Hasil Uji $t$

\begin{tabular}{|c|r|r|r|r|c|}
\hline Variable & Coefficient & Std. Error & t-Statistic & Prob. & Description \\
\hline C & 27.80698 & 17.09920 & 1.626215 & 0.1041 & - \\
\hline OWCON? & -2.313118 & 3.664681 & -0.631192 & 0.5280 & Insignificant \\
\hline MANOW? & 6.281584 & 5.545228 & 1.132791 & 0.2575 & Insignificant \\
\hline FOREIGNOW? & 6.218206 & 2.260300 & 2.751053 & 0.0060 & Signifikan Positif \\
\hline INSTOW? & 1.131935 & 3.052572 & 0.370814 & 0.7108 & Insignificant \\
\hline GROWTH? & $1.24 \mathrm{E}-12$ & $2.53 \mathrm{E}-12$ & 0.488241 & 0.6254 & Insignificant \\
\hline LN_TASSET? & 1.620403 & 0.594349 & 2.726348 & 0.0065 & \\
\hline AUDTYPE? & 4.518248 & 1.660036 & 2.721777 & 0.0066 & \\
\hline
\end{tabular}

Sumber: Data sekunder yang diolah (2020).

Tabel 5 menjelaskan hasil uji t per masing masing variabel independen yang akan dianalisa untuk mendapati variabel mana saja yang berpengaruh signifikan positif, negatif maupun tidak berpengaruh signifikan terhadap keterlambatan audit. Berikut hasil analisa per hipotesis yang dibuat.

\section{$H_{1}$ : Kepemilikan}

terkonsentrasi

mempunyai pengaruh Positif terhadap keterlambatan audit.

Hasil uji t menyatakan kepemilikan terkonsenterasi tidak berpengaruh signifikan atas keterlambatan audit pada perusahaan yang terdaftar di BEI. Hal ini dikarenakan konsentrerasi kepemilikan perusahaan perbankan di Indonesia lebih tersentralisasi, dan oleh kerena itu juga disarankan menggunakan pengukuran 5 kepemilikan saham terbesar sebagai acuan di negara berkembang (Setiawan \& Nahumury, 2014). Hasil ini sesuai dengan (Afify, 2009; Alsmady, 2018; Mouna \& Anis, 2013b, 2013a; Setiawan \& Nahumury, 2014). Namun, hasil penelitian ini tidak sependapat dengan (Lee \& Jahng, 2008). Kesimpulan pada hasil uji t terhadap hipotesis pertama ditolak.
$\mathrm{H}_{2}$ : Kepemilikan manajerial mempunyai pengaruh negatif terhadap Keterlambatan audit

Hasil uji t menyatakan bahwa kepemilikan manajerial tidak memiliki pengaruh signifikan atas keterlambatan audit pada perusahaan yang terdaftar di BEI. Huafang dan Jianguo (2007) menjelaskan terdapat dua alasan mengapa kepemilikan manajerial tidak berpengaruh signifikan:

1. Rendahnya proporsi kepemilikan manajerial sehinggs tidak memberikan motivasi yang cukup kepada manajer senior dalam mengawasi keterlambatan audit.

2. Motivasi pemberian kepemilikan manajerial bukan diberikan kepada manajer yang berkinerja baik. Namun, diberikan kepada manajer yang berkualifikasi di perusahaan berdasarkan faktor historisnya. Sehungga motivasi ini tidak memberikan pengaruh yang efektif.

Perolehan ini dukung oleh penelitan yang dilakukan Alsmady (2018); Fujianti (2016); Puspitaningrum dan Atmini (2012), 
Kesimpulan pada hasil uji $t$ terhadap hipotesis kedua ditolak.

$H_{3}$ : kepemilikan asing mempunyai pengaruh negatif terhadap keterlambatan audit

Hasil uji $\mathrm{t}$ medapati nilai signifikan 0.0060 , yang berarti kepeilikan asing dapat berpengaruh signifikan postif atas keterlambatan audit karena memenuhi kriteria dibawah 0,05 . S. C. Lee, Rhee, dan Yoon (2018) menjelaskan kepemilikan asing biasanya memonitor secara mendalam seluruh proses manajamen sehingga melambatkan/menambah keterlambatan audit. Hasil ini konsisten dengan (Tazik \& Mohamed, 2014). Kesimpulan pada hasil uji $\mathrm{t}$ terhadap hipotesis ketiga ditolak.

$\mathrm{H}_{4}$ : $\quad$ kepemilikan institusional mempunyai pengaruh negatif terhadap keterlambatan audit

Hasil uji variabel kepemilikan institusional mendapati nilai signifikan 0.7108. yang artinya kepemilikan institusional tidak berpengaruh signifikan atas keterlambatan audit, dikarenakan hasil uji tersebut tidak memenuhi krietria >0.05. Faktor ini diduga disebabkan oleh perilaku investor institusional seperti investor trasient yang hanya mengincar return dan imbal balik (Mohammed et al., 2018). Lalu faktor yang lain adalah pihak institusi lebih terfokus kepada tingkat profitability ketimbang keterlambatan audit (Azhari \& Nuryatno, 2019). Hasil ini mendukung penelitian oleh Hashim (2017), Mouna dan Anis (2013a, 2013b). Kesimpulan pada hasil uji t terhadap hipotesis keempat ditolak.

$H_{5}$ : $\quad$ Pertumbuhan perusahaan mempunyai pengaruh negatif terhadap keterlambatan audit

Hasil uji variabel pertumbuhan perusahaan mendapati nilai signifikan 0.6254 yang artinya kepemilikan institusional tidak berpengaruh signifikan atas keterlambatan audit, dikarenakan hasil uji tersebut tidak memenuhi krietria $<0,05$. Salah satu faktor penyebabnya ialah sfiat pertumbuhan perusahaan akan mudah berubah dan akan "membawa ke era baru audit", karena pertumbuhan perusahaan tidak dapat diprediksi pengaruhnya. Dan oleh karena itu para peneliti harus memilih sampel jenis industri yang akan diambil agar relevan (Durand, 2019). Kesimpulan pada hasil uji t terhadap hipotesis kelima ditolak.

\section{KESIMPULAN}

Kesimpulan dari hasil analisa data mendapati satu variabel yang memiliki pengaruh signifikan dari 5 variabel independen yaitu variabel kepemilikan asing. Berikut kesimpulan dari analisa hasil penelitian:

1. Hanya terdapat satu variabel yang memiliki pengaruh signifikan yaitu kepemilikan asing, dimana kepemilikan asing berpenagruh signifikan positif dan itupun tidak sesuai dengan hipotesis yang diajukan.

2. Hasil analisa data menunjukkan variabel Variabel konsentrasi kepemilkan, kepemilikan manajemen, kepemilikan institusional, serta pertumbuhan perusahaan tidak memiliki penagruh yang signifikan.

3. Hasil koefisien determinasi menunjukkan bahwa dari 5 variabel indpenden dan 2 variabel kontrol dapat menjelaskan $64 \%$ dari keseluruhan model penelitian.

\section{DAFTAR PUSTAKA}

Afify, H. A. E. (2009). Determinants of audit report lag: Does implementing corporate governance have any impact? Empirical evidence from Egypt. Journal of Applied Accounting Research, 10(1), 56-86. https://doi.org/10.1108/09675420910963 397

Alsmady, A. A. (2018). Ownership Structure and its Endogeneity Effect on the Quality of Financial Reporting. International Journal of Academic Research in Business and Social Sciences, (June). https://doi.org/10.6007/IJARBSS/v8- 
i3/3946

Azhari, F., \& Nuryatno, M. (2019). Opini Audit Pemoderasi Pengaruh Profitabilitas, Ukuran Perusahaan, Kepemilikan Institusional, Dan Komite Audit Terhadap Ketepatanwaktuan. Jurnal Ilmiah Akuntansi Dan Bisnis, 1933.

https://doi.org/10.24843/jiab.2019.v14.i0 1.p03

Chandler $\mathrm{Ku}$ Nor Izah $\mathrm{Ku}$ Ismail Roy. (2004). The timeliness of quarterly financial reports of companies in Malaysia. Asian Review of Accounting, 23(3), 232-255. https://doi.org/10.1108/ARA-04-20120017

Creswell, J. w. (2012). educational research: planning,conducting and evaluating.

Durand, G. (2019). The determinants of audit report lag: a meta-analysis. Managerial Auditing Journal, 34(1), 44-75. https://doi.org/10.1108/MAJ-06-20171572

Dyer, J. C., \& McHugh, A. J. (1975). The Timeliness of the Australian Annual Report. Journal of Accounting Research, 13(2),

204. https://doi.org/10.2307/2490361

Fujianti, L. (2016). Analysis Market Reaction on Timeliness Reporting: Study on Indonesia Stock Analysis Market Reaction on Timeliness Reporting: Study on Indonesia Stock Exchange. (March 2016).

Habib, A. (2015). The new Chinese accounting standards and audit report lag. International Journal of Auditing, 19(1), $1-14$. https://doi.org/10.1111/ijau.12030

Hashim, J. U. (2017). Does Ownership Characteristics Have Any Impact on Audit Report Lag? Evidence of Malaysian Listed Companies. World Applied Sciences Journal, 35(9), 18261838.

https://doi.org/10.5829/idosi.wasj.2017.1 826.1838

Huafang, X., \& Jianguo, Y. (2007).
Ownership structure, board composition and corporate voluntary disclosure: Evidence from listed companies in China. Managerial Auditing Journal, 22(6), 604-619. https://doi.org/10.1108/02686900710759 406

Ismail, H., Mustapha, M., \& Ming, C. O. (2012). Timeliness of audited financial reports of Malaysian listed companies. International Journal of Business and Social Science Vol. 3 No. 22 [Special Issue - November 2012], 3(22), 242247. https://doi.org/10.1577/T05-230.1

Lee, H. Y., \& Jahng, G. J. (2008). Determinants of audit report lag: Evidence from Korea - An examination of auditor-related factors. Journal of Applied Business Research, 24(2), 2744.

https://doi.org/10.19030/jabr.v24i2.1352

Lee, S. C., Rhee, M., \& Yoon, J. (2018). Foreign monitoring and audit quality: Evidence from Korea. Sustainability (Switzerland), 10(9), 1-22. https://doi.org/10.3390/su10093151

Mazkiyani, N., \& Handoyo, S. (2017). Audit report lag of listed companies in Indonesia stock exchange. Jurnal Aplikasi Bisnis, 17(1), 77-95. https://doi.org/10.20885/jabis.vol17.iss1. art5

Mohammed, I. A., Che-ahmad, A., \& Malek, M. (2018). Shareholder's involvement in the audit committee, audit quality and financial reporting lag in Nigeria Shareholder' $s$ involvement in the audit committee, audit quality and financial reporting lag in Nigeria. Business and Economic Horizons, (May). https://doi.org/10.15208/beh.2018.26

Mouna, A., \& Anis, J. (2013a). Financial reporting delay and corporate dovernance from Tunisia. International Journal of Information, Business and Management, 5(4), 32-46.

Mouna, A., \& Anis, J. (2013b). Financial Reporting Delay and Investors Behavior: Evidence from Tunisia. International Journal Management 
Business, 3(1), 57-67.

Ocak, M., \& Özden, E. A. (2018). Signing auditor-specific characteristics and audit report lag: A research from Turkey. Journal of Applied Business Research, $34(2)$, 277-294. https://doi.org/10.19030/jabr.v34i2.1012 9

Ohaka, J., \& Akani, F. N. (2017). Timeliness and Relevance of Financial Reporting in Nigerian Quoted Firms. Management and Organizational Studies, 4(2), 55. https://doi.org/10.5430/mos.v4n2p55

OJK. (2016). PERATURAN OTORITAS JASA KEUANGAN NOMOR 29 /POJK.04/2016 TENTANG LAPORAN TAHUNAN EMITEN ATAU PERUSAHAAN PUBLIK.

Puasa, S., \& Ahmad, A. (2014). Audit Committee and Timeliness of Financial Reporting: Malaysian Public Listed Companies. Middle-East Journal of Scientific Research, 22(2), 162-175. https://doi.org/10.5829/idosi.mejsr.2014. 22.02.21886

Puspitaningrum, D., \& Atmini, S. (2012). 2nd Annual International Conference on Accounting and Finance ( $A F 2012$ ) Corporate governance mechanism and the level of internet financial reporting: Evidence from Indonesian companies. 2(Af), 157-166. https://doi.org/10.1016/S22125671(12)00075-5

Setiawan, G., \& Nahumury, J. (2014). The effect of board of commissioners, audit committee, and stock ownership concentration on audit report lag of banking companies in Indonesia Stock Exchange. The Indonesian Accounting Review, 4(01), 15. https://doi.org/10.14414/tiar.v4i01.280

Tazik, H., \& Mohamed, Z. M. (2014). Accounting Information System Effectiveness, Foreign Ownership and Timeliness of Corporate Financial Report. 1-12.

Togasima, C. N., \& Christiawan, Y. J. (2012). AUDIT REPORT LAG PADA PERUSAHAAN YANG TERDAFTAR
DI BURSA EFEK INDONESIA PADA TAHUN 2012. BUSINESS ACCOUNTING REVIEW. 